\title{
EDITORIAL
}

\section{RETORNANDO AL PASADO: 60 AÑOS EN EL ENTENDIMIENTO DE CÓMO LAS CÉLULAS Y LOS ORGANISMOS SE DESARROLLAN}

\author{
"Si usted está realmente interesado en algo, sigua adelante - no se rinda". Profesor John Gurdon. \\ Orietta BeLtrán, MD, MSc ${ }^{1}$ \\ ${ }^{1}$ Médica, MSc Genética Humana. Profesora Asistente Universidad Militar Nueva Granada, \\ Facultad de Medicina. Bogotá, Colombia.
}

Correspondencia: orietta.beltran@unimilitar.edu.co

El primer intento de reprogramar una célula somática a una célula pluripotente se realizó en 1.952 cuando Robert Briggs y Thomas King (1) transfiriendo exitosamente núcleos de blastocitos en ovocitos de Rana pipiens obteniendo embriones viables. Sin embargo, ellos dedujeron que la técnica de transferencia nuclear somática (SCTN) no era aplicable en células diferenciadas por el carácter irreversible de los procesos de diferenciación. Posteriormente, en 1.962 el biólogo John Gurdon de la Universidad de Cambrigde hizo un descubrimiento revolucionario: demostró la formación de embriones que se desarrollaron en renacuajos de Xenopus laevis a partir de la transferencia de núcleos de células intestinales de ranas adultas en ovocitos, evidenciando que los genomas de las células somáticas mantienen su capacidad de generar organismos clonados viables y evidenciando que el proceso de diferenciación es un mecanismo reversible mediante la reprogramación nuclear debida a modificaciones epigenéticas regulado por la existencia de factores, -no identificados-, que inducen la pluripotencia. Adicionalmente, otra de las observaciones de John Gurdon fue que los genes no se perdían, sino que tenían una expresión diferencial $(2,3,4)$. Tres décadas más tarde, en 1.996, el embriólogo Ian Wilmut y colaboradores (5) lograron la clonación exitosa en un mamífero, la oveja Dolly, la cual fue seguida de la clonación de vacas, cerdos, ratones, cabras, conejos y gatos, así como la clonación con una menor eficiencia en ratas, primates no humanos y perros por varios investigadores $(6,7,8)$.

Adicionalmente, en 1.998 el biólogo James Thomson de la Universidad de Winsconsin logró el aislamiento y caracterización de células madre embrionarias humanas
(9), lo cual señaló la gran posibilidad de utilizarlas para aplicaciones medicas a través de la obtención in vitro de líneas celulares de todos los linajes, como por ejemplo cardiomiocitos, osteoblastos, condrocitos, hepatocitos y neuronas. Pero las preocupaciones éticas en torno a la investigación con células madre embrionarias son controversiales, debido a que habitualmente se extraen mediante la destrucción de embriones humanos que las clínicas de fertilidad descartan. Igualmente, la técnica de SCTN tiene implicaciones éticas, debido a la cuestionable necesidad de utilizar numerosos ovocitos. Otra de las desventajas técnicas de la SCTN son su eficiencia baja (1-4\%) y la confirmación de anomalías cromosómicas estructurales en algunas líneas celulares obtenidas lo que hace que sea una herramienta limitada en la producción de células o tejidos autólogos para uso terapéutico (6). Sin embargo, un aporte trascendental de la clonación de organismos a través de técnica SCTN, fue que demostró que cuando un núcleo es transferido en el citoplasma de los ovocitos, se producen cambios en la estructura de la cromatina que regulan de manera reversible la diferenciación, constituyéndose en una importante prueba de la plasticidad del desarrollo $(6,8)$.

Por otra parte, otros investigadores aplicaron la técnica de fusión de células somáticas con células madre embrionarias, para obtener células pluripotentes. Richard Miller y Frank Ruddle en 1976, utilizando esta técnica demostraron que timocitos de ratón adquirían pluripotencia luego de la fusión celular con células de carcinoma embrionarios (9). Uno de los estudios más interesantes fueron de Chad Cowan y colaboradores en 2005, quienes lograron fusionar fibroblastos humanos con células madre embrionarias humanas, 
obteniendo células híbridas con características morfológicas y expresión génica de patrones típicos de células madre embrionarias como los genes involucrados en la pluripotencia (Oct4, Nanog, TDGF1 y Rex1), con un silenciamiento específico de los genes del estado somático en todo el genoma y la evidencia de cambios epigenéticos en el promotor de Oct4 (10).

Sin embargo, un descubrimiento espectacular ocurrió en 2006 cuando Shinya Yamanaka y Kazutochi Takahashi, investigadores del Departamento de Biología de Células Madre de la Universidad de Kyoto en Japón, determinaron que la transfección viral de cuatro genes (Oct4, Sox2 KLF4 yc-Myc, abreviados OSKM) en fibroblastos de ratón adulto generaba células con las características de células madre embrionarias, la cuales denominaron células madre pluripotentes inducidas (iPS) (11); y que éstos mismos factores son requeridos en la generación de iPS humanas a partir de fibroblastos humanos (12). Las células resultantes no parecen ser sustancialmente diferentes de las células madre embrionarias y eventualmente puede proporcionar una fuente adecuada de diferentes tipos celulares específicos para cada paciente (13).

El legado científico de John Gurdon y Shinya Yamanaka de que la diferenciación celular no es un proceso unidireccional e irreversible ha implicado el avance en el conocimiento de la biología de las células madre y los mecanismos de regulación epigenética. La inducción de pluripotencia a través de factores específicos, a veces llamados "los factores de Yamanaka", ha permitido una transición rápida en el uso de células madre pluripotentes inducidas en el estudio de modelos fisiopatológicos, descubrimiento de genes y medicamentos, estudios del desarrollo embrionario y la diferenciación, así como una potencial fuente de terapia celular y de las líneas celulares específicas de enfermedades para evaluar posibles blancos y agentes terapéuticos.

Recientemente, la Asamblea de los Premios Nobel anuncio que John Gurdon junto con Shinya Yamanaka han sido galardonados con el Premio Nobel de Fisiología o Medicina en 2012, por demostrar que las células diferenciadas adultas pueden ser reprogramadas para convertirse en células inmaduras "madre", capaces de desarrollar todos los tejidos del cuerpo (14).
El reto actual de los investigadores en el campo de la Células Madre y la Medicina Regenerativa es entender el funcionamiento molecular de la pluripotencia tanto a nivel genético y epigenético, e incrementar la eficiencia y la seguridad de las técnicas de reprogramación nuclear en la aplicación clínica de las iPS.

\section{Referencias}

1. Briggs R, King TJ. Transplantation of Living Nuclei From Blastula Cells into Enucleated Frogs' Eggs. Proc Natl Acad Sci U S A. 1952 May;38(5):455-63.

2. Gurdon JB. The developmental capacity of nuclei taken from intestinal epithelium cells of feeding tadpoles. J Embryol Exp Morphol. 1962 Dec;10:622-40.

3. Gurdon JB. The transplantation of nuclei between two species of Xenopus. Dev Biol. 1962 Aug;5:68-83

4. Gurdon JB. Adult frogs derived from the nuclei of single somatic cells. Dev Biol. 1962 Apr;4:256-73.

5. Campbell KH, McWhir J, Ritchie WA, Wilmut I. Sheep cloned by nuclear transfer from a cultured cell line. Nature. $1996 \mathrm{Mar}$ 7;380(6569):64-6.

6. Wilmut I, Beaujean N, de Sousa PA, Dinnyes A, King TJ, Paterson LA, Wells DN, Young LE. Somatic cell nuclear transfer. Nature. 2002 Oct 10;419(6907):583-6.

7. Byrne JA, Pedersen DA, Clepper LL, Nelson M, Sanger WG, Gokhale S, Wolf DP, Mitalipov SM. Producing primate embryonic stem cells by somatic cell nuclear transfer. Nature. 2007 Nov 22;450(7169):497-502.

8. Thomson JA, Itskovitz-Eldor J, Shapiro SS, Waknitz MA, Swiergiel JJ, Marshall VS, Jones JM. Embryonic stem cell lines derived from human blastocysts. Science. 1998 Nov 6;282(5391):11457. Erratum in: Science 1998 Dec 4;282(5395):1827.

9. Wilmut I, Paterson L. Somatic cell nuclear transfer. Oncol Res. 2003;13(6-10):303-7.

10. Miller RA, Ruddle FH. Pluripotent teratocarcinoma-thymus somatic cell hybrids. Cell. 1976 Sep;9(1):45-55.

11. Cowan CA, Atienza J, Melton DA, Eggan K. Nuclear reprogramming of somatic cells after fusion with human embryonic stem cells. Science. 2005 Aug 26;309(5739):1369-73.

12. Takahashi K, Yamanaka S. Induction of pluripotent stem cells from mouse embryonic and adult fibroblast cultures by defined factors. Cell. 2006 Aug 25;126(4):663-76.

13. Takahashi K, Tanabe K, Ohnuki M, Narita M, Ichisaka T, Tomoda K, Yamanaka S. Induction of pluripotent stem cells from adult human fibroblasts by defined factors. Cell. 2007 Nov 30;131(5):861-72.

14. Gurdon JB, Melton DA. Nuclear reprogramming in cells. Science. 2008 Dec 19;322(5909):1811-5.

15. Vogel G, Normile D. Nobel Prize in physiology or medicine. Reprogrammed cells earn biologists top honor. Science. 2012 Oct 12;338(6104):178-9. 


\title{
EDITORIAL
}

\section{RETURNING TO THE PAST: 60 YEARS IN THE UNDERSTANDING OF HOW CELLS AND ORGANISMS DEVELOP}

\author{
"If you're really interested in something, keep going - don't give up." Professor John Gurdon. \\ Orietta BeLtrán, MD, MSc ${ }^{1}$ \\ ${ }^{1}$ Médica, MSc Genética Humana. Profesora Asistente Universidad Militar Nueva Granada, \\ Facultad de Medicina. Bogotá, Colombia.
}

Correspondencia: orietta.beltran@unimilitar.edu.co

The first attempt to reschedule a somatic cell into a pluripotent stem was performed in 1952 when Robert Briggs and Thomas King (1) successfully transferred nuclei of Rana pipiens blastocysts to oocytes obtaining viable embryos. However, they inferred that the somatic cell nuclear transfer (SCNT) technique was not applicable to differentiated cells due to the irreversible character of differentiation processes. Subsequently, in 1962, the biologist John Gurdon, University of Cambridge, made a revolutionary discovery: he demonstrated the formation of embryos developed in Xenopus laevis tadpoles starting from transference of adult frogs' gut cells nuclei to oocytes thus evidencing that genomes of somatic cells maintain their ability to generate viable cloned organisms and that the differentiation process is a reversible mechanism through nuclear reschedule due to epigenetic modifications, regulated by the existence of -unidentified- factors which induce pluripotency. Additionally, another John Gurdon's observation was that genes didn't get lost but they had a differential expression $(2,3,4)$. Three decades later, in 1996, the embryologist Ian Wilmut et al (5) achieved successful clonation in a mammal, Dolly the sheep, that was followed by cows, pigs, mice, goats, and cats clonation as well as less efficient clonation in rats, non human primates and dogs by several investigators $(6,7,8)$.

Furthermore, in 1998, the biologist James Thomson, University of Wisconsin, managed to isolate and typify human embryonic stem cells (9) which pointed out the great possibility of using them for medical applications through obtaining in vitro cell lines from all lineages, for example, cardiomyocytes, osteoblasts, chondrocytes, hepatocytes and neurons. But ethical concerns around investigation with embryonic stem cells are controversial, because usually they are extracted through destruction of human embryos discarded by fertility clinics. Likewise, the SCNT technique has ethical implications due to the questionable need to use oocytes. Another technical disadvantage of SCNT is its low efficiency (1-4\%) and confirmation of structural chromosomic abnormalities in some of the obtained cell lines which makes it a limited tool in the production of autologous cells or tissues for therapeutic use (6). However, it was a transcendental contribution of organisms through the SCNT which demonstrated that when a nucleus is transferred in the oocyte cytoplasm, changes in the chromatin structure are produced which regulate reversibly the differentiation, becoming an important test of developmental plasticity $(6,8)$.

On the other hand, other investigators applied the fusion of somatic cells with embryonic stem cells technique in order to obtain pluripotent cells. By using this technique, Richard Miller and Frank Ruddle, in 1976, demonstrated that mice thymocytes gained pluripotency following cell fusion with embrionary carcinoma cells (9). One of the most interesting studies was that of Chad Cowan et al in 2005, who were able to merge human fibroblasts with embryonic stem cells, thus obtaining hybrid cells with morphological features and gene expression of typical patterns of embryonic stem cells as well as genes involved in pluripotency (Oct4, Nanog, TDGF1 and Rex1), with specific silencing of somatic status genes in the whole genome and evidence of epigenetic changes in the Oct4 promoter (10).

Nevertheless, a striking discovery took place in 2006 when Shinya Yamanaka and Kazutochi Takahashi, investigators of the Stem Cells Biology Department, Kyoto 
University, Japan, determined that viral transfection of four genes (Oct4, Sox2 KLF4 yc-Myc, acronym OSKM) in adult mice fibroblasts generated cells with embryonic stem cells features which were named induced pluripotent stem cells (iPS) (11); besides, these same factors were required in the generation of human iPS from human fibroblasts (12). The resultant cell don't seem to be substantially different from embryonic stem cells and eventually can provide an appropriate source of different cell types specific for each patient (13).

John Gurdon and Shinya Yamanaka's scientific legacy in that cell differentiation is not an unidirectional and irreversible process has involved the progress in the knowledge of stem cells biology and epigenetic mechanisms regulation. The induction of pluripotency through specific factors, sometimes called "Yamanaka factors", has allowed a rapid transition in the use of induced pluripotent stem cells in the study of pathophysiological models, discovery of genes and drugs, embryonic development and differentiation studies as well as a potential source of cell therapy and specific disease cell lines to assess feasible targets and therapeutic agents.

Recently, the Nobel Prize Assembly announced that John Gurdon, along with Shinya Yamanaka had been awarded with the Nobel Prize of Physiology or Medicine in 2012 for demonstrating that adult differentiated cells can be rescheduled to become immature "stem" cells that are capable of developing any kind of body tissue (14).

The current challenge of investigators in the field of Stem Cells and Regenerative Medicine is to understand the molecular functioning of pluripotency both at the genetic and epigenetic level, and increase the efficiency and safety of nuclear reschedule techniques in the clinical application of iPS.

\section{References}

1. Briggs R, King TJ. Transplantation of Living Nuclei From Blastula Cells into Enucleated Frogs' Eggs. Proc Natl Acad Sci U S A. 1952 May;38(5):455-63.

2. Gurdon JB. The developmental capacity of nuclei taken from intestinal epithelium cells of feeding tadpoles. J Embryol Exp Morphol. 1962 Dec;10:622-40.

3. Gurdon JB. The transplantation of nuclei between two species of Xenopus. Dev Biol. 1962 Aug;5:68-83

4. Gurdon JB. Adult frogs derived from the nuclei of single somatic cells. Dev Biol. 1962 Apr;4:256-73.

5. Campbell KH, McWhir J, Ritchie WA, Wilmut I. Sheep cloned by nuclear transfer from a cultured cell line. Nature. $1996 \mathrm{Mar}$ 7;380(6569):64-6.

6. Wilmut I, Beaujean N, de Sousa PA, Dinnyes A, King TJ, Paterson LA, Wells DN, Young LE. Somatic cell nuclear transfer. Nature. 2002 Oct 10;419(6907):583-6.

7. Byrne JA, Pedersen DA, Clepper LL, Nelson M, Sanger WG, Gokhale S, Wolf DP, Mitalipov SM. Producing primate embryonic stem cells by somatic cell nuclear transfer. Nature. $2007 \mathrm{Nov}$ 22;450(7169):497-502.

8. Thomson JA, Itskovitz-Eldor J, Shapiro SS, Waknitz MA, Swiergiel JJ, Marshall VS, Jones JM. Embryonic stem cell lines derived from human blastocysts. Science. 1998 Nov 6;282(5391):11457. Erratum in: Science 1998 Dec 4;282(5395):1827.

9. Wilmut I, Paterson L. Somatic cell nuclear transfer. Oncol Res. 2003;13(6-10):303-7.

10. Miller RA, Ruddle FH. Pluripotent teratocarcinoma-thymus somatic cell hybrids. Cell. 1976 Sep;9(1):45-55.

11. Cowan CA, Atienza J, Melton DA, Eggan K. Nuclear reprogramming of somatic cells after fusion with human embryonic stem cells. Science. 2005 Aug 26;309(5739):1369-73.

12. Takahashi K, Yamanaka S. Induction of pluripotent stem cells from mouse embryonic and adult fibroblast cultures by defined factors. Cell. 2006 Aug 25;126(4):663-76.

13. Takahashi K, Tanabe K, Ohnuki M, Narita M, Ichisaka T, Tomoda K, Yamanaka S. Induction of pluripotent stem cells from adult human fibroblasts by defined factors. Cell. 2007 Nov 30;131(5):861-72.

14. Gurdon JB, Melton DA. Nuclear reprogramming in cells. Science. 2008 Dec 19;322(5909):1811-5.

15. Vogel G, Normile D. Nobel Prize in physiology or medicine. Reprogrammed cells earn biologists top honor. Science. 2012 Oct 12;338(6104):178-9. 


\title{
EDITORIAL
}

\section{VOLTANDO AO PASSADO: 60 ANOS NO ENTENDIMENTO DE COMO AS CÉLULAR E OS ORGANISMOS SE DESENVOLVEM}

\author{
"Se você realmente está interessado em algo, continue em frente, não se renda". Professor John Gurdon. \\ ORIetTa BeLtrán, MD, MSc $\mathrm{C}^{1}$ \\ ${ }^{1}$ Médica, MSc Genética Humana. Profesora Asistente Universidad Militar Nueva Granada, \\ Facultad de Medicina. Bogotá, Colombia.
}

Correspondencia: orietta.beltran@unimilitar.edu.co

A primeira tentativa de reprogramar una célula somática a uma célula pluripotente realizou-se em 1.952 quando Robert Briggs e Thomas King (1) transferindo com sucesso exitosamente núcleos de blastócitos em ovócitos de Rã pipiens obtendo embriões viáveis. Porém, eles deduziram que a técnica de transferência nuclear somática (SCTN) não era aplicável em células diferenciadas pelo caráter irreversível dos processos de diferenciação. Posteriormente, em 1.962 o biólogo John Gurdon da Universidade de Cambridge fez uma descoberta revolucionária: demonstrou a formação de embriões que desenvolvem-se em girinos de Xenopus laevis a partir da transferência de núcleos de células intestinais de rãs adultas em ovócitos, evidenciando que os genomas das células somáticas mantêm sua capacidade de gerar organismos clonados viáveis e evidenciando que o processo de diferenciação é um mecanismo reversível mediante a reprogramação nuclear devida a modificações epigenéticas reguladas pela existência de fatores, - não identificados -, que induzem à pluripotência. Além disso, outra das observações de John Gurdon foi que os genes não perdiam, senão que tinham uma expressão diferencial $(2,3,4)$. Três décadas mais tarde, em 1.996, o embriologista Ian Wilmut e colaboradores (5) conseguiram clonar com sucesso um mamífero, a ovelha Dolly, que foi acompanhada da clonagem de vacas, porcos, ratos, cabras, coelhos e gatos, bem como a clonagem com uma maior eficiência de ratos, primatas não humanos e cachorros, por vários pesquisadores $(6,7,8)$.

Além disso, em 1.998 o biólogo James Thomson da Universidade de Winsconsin conseguiu o isolamento e caracterização de células tronco embrionárias humanas (9), o cual señaló a gran posibilidad de utilizarlas para aplicações médicas através da obtenção in vitro de linhas celulares de todas as linhagens, como por exemplo cardiomiocitos, osteoblastos, condrocitos, hepatocitos e neurônios. Mas, as preocupações éticas ao redor da pesquisa com células tronco embrionárias são controversiais, devido a que habitualmente se extraem mediante a destruição de embriões humanos que as clínicas de fertilidade descarta. Da mesma forma, a técnica de SCTN tem implicações éticas, devido à questionável necessidade de utilizar numerosos ovócitos. Outra das desvantagens técnicas da SCTN são sua baixa eficiência (1-4\%) e a confirmação de anomalias cromossômicas estruturais em algumas linhas celulares obtidas o que faz que seja uma ferramenta limitada na produção de células ou tecidos autólogos para uso terapêutico (6). Porém, uma contribuição transcendental da clonagem de organismos através da técnica SCTN, foi que demonstrou que quando um núcleo é transferido no citoplasma dos ovócitos, se produzem mudanças na estrutura da cromatina que regulam de forma reversível a diferenciação, constituindo-se em una importante prova da plasticidade do desenvolvimento $(6,8)$.

Por outra parte, outros pesquisadores aplicaram a técnica de fusão células somáticas com células tronco embrionárias, para obter células pluripotentes. Richard Miller e Frank Ruddle em 1976, utilizando esta técnica demonstraram que timócitos de rato adquiriam pluripotencia depois da fusão celular com células de carcinoma embrionários (9). Um dos estudos mais interessantes foi o de Chad Cowan e colaboradores em 2005, que conseguiram fundir fibroblastos humanos com células 
tronco embrionárias humanas, obtendo células híbridas com características morfológicas e expressão gênica de padrões típicos de células tronco embrionárias como os genes envolvidos na pluripotência (Oct4, Nanog, TDGF1 e Rex1), com um silenciamiento específico dos genes do estado somático em todo o genoma e a evidência de mudanças epigenéticas no promotor de Oct4 (10).

Porém, um descobrimento espetacular ocorreu em 2006 quando Shinya Yamanaka e Kazutochi Takahashi, pesquisadores do Departamento de Biologia de Células Tronco da Universidade de Kyoto no Japão, determinaram que a transfeção viral de quatro genes (Oct4, Sox2 KLF4 yc-Myc, abreviados OSKM) em fibroblastos de rato adulto gerava células com as características de células tronco embrionárias, as quais denominaram células tronco pluripotentes induzidas (iPS) (11); e que estes mesmo fatores são requeridos na geração de iPS humanas a partir de fibroblastos humanos (12). As células resultantes não parecem ser substancialmente diferentes das células tronco embrionárias e eventualmente pode proporcionar una fonte adequada de diferentes tipos celulares específicos para cada paciente (13).

O legado científico de John Gurdon e Shinya Yamanaka de que a diferenciação celular não é um processo unidirecional e irreversível ha implicado o avance no conhecimento da biologia das células tronco e dos mecanismos de regulação epigenética. A indução de pluripotencia através de fatores específicos, as vezes chamados "os fatores de Yamanaka", permitiu uma transição rápida no uso de células tronco pluripotentes induzidas no estudo de modelos fisiopatológicos, descobrimento de genes e medicamentos, estudos do desenvolvimento embrionário e a diferenciação, bem como una potencial fonte de terapia celular e das linhas celulares específicas de doenças para avaliar possíveis alvos e agentes terapêuticos.

Recentemente, a Assembleia dos Prêmios Nobel anuncio que John Gurdon junto com Shinya Yamanaka foram os ganhadores do Premio Nobel de Fisiologia ou Medicina em 2012, por demonstrar que as células diferenciadas adultas podem ser reprogramadas para converter-se em células imaturas "tronco", capazes de desenvolver todos os tecidos do corpo (14).
O atual desafio dos pesquisados no campo das Células Madre e da Medicina Regenerativa é entender o funcionamento molecular da pluripotência tanto a nível genético e epigenético, e aumentar a eficiência e a segurança das técnicas de reprogramação nuclear na aplicação clínica das iPS.

\section{Referências}

1. Briggs R, King TJ. Transplantation of Living Nuclei From Blastula Cells into Enucleated Frogs' Eggs. Proc Natl Acad Sci U S A. 1952 May;38(5):455-63.

2. Gurdon JB. The developmental capacity of nuclei taken from intestinal epithelium cells of feeding tadpoles. J Embryol Exp Morphol. 1962 Dec;10:622-40.

3. Gurdon JB. The transplantation of nuclei between two species of Xenopus. Dev Biol. 1962 Aug;5:68-83

4. Gurdon JB. Adult frogs derived from the nuclei of single somatic cells. Dev Biol. 1962 Apr;4:256-73.

5. Campbell KH, McWhir J, Ritchie WA, Wilmut I. Sheep cloned by nuclear transfer from a cultured cell line. Nature. 1996 Mar 7;380(6569):64-6.

6. Wilmut I, Beaujean N, de Sousa PA, Dinnyes A, King TJ, Paterson LA, Wells DN, Young LE. Somatic cell nuclear transfer. Nature. 2002 Oct 10;419(6907):583-6.

7. Byrne JA, Pedersen DA, Clepper LL, Nelson M, Sanger WG, Gokhale S, Wolf DP, Mitalipov SM. Producing primate embryonic stem cells by somatic cell nuclear transfer. Nature. 2007 Nov 22;450(7169):497-502.

8. Thomson JA, Itskovitz-Eldor J, Shapiro SS, Waknitz MA, Swiergiel JJ, Marshall VS, Jones JM. Embryonic stem cell lines derived from human blastocysts. Science. 1998 Nov 6;282(5391):11457. Erratum in: Science 1998 Dec 4;282(5395):1827.

9. Wilmut I, Paterson L. Somatic cell nuclear transfer. Oncol Res. 2003;13(6-10):303-7.

10. Miller RA, Ruddle FH. Pluripotent teratocarcinoma-thymus somatic cell hybrids. Cell. 1976 Sep;9(1):45-55.

11. Cowan CA, Atienza J, Melton DA, Eggan K. Nuclear reprogramming of somatic cells after fusion with human embryonic stem cells. Science. 2005 Aug 26;309(5739):1369-73.

12. Takahashi K, Yamanaka S. Induction of pluripotent stem cells from mouse embryonic and adult fibroblast cultures by defined factors. Cell. 2006 Aug 25;126(4):663-76.

13. Takahashi K, Tanabe K, Ohnuki M, Narita M, Ichisaka T, Tomoda K, Yamanaka S. Induction of pluripotent stem cells from adult human fibroblasts by defined factors. Cell. 2007 Nov 30;131(5):861-72.

14. Gurdon JB, Melton DA. Nuclear reprogramming in cells. Science. 2008 Dec 19;322(5909):1811-5.

15. Vogel G, Normile D. Nobel Prize in physiology or medicine. Reprogrammed cells earn biologists top honor. Science. 2012 Oct 12;338(6104):178-9. 